\title{
Potent and Selective Estrogen Receptor-Beta Agonists Which Enhance Memory Consolidation in an Ovariectomized Mouse Model ${ }^{\dagger}$
}

\author{
Alicia M. Hanson ${ }^{1}$, Iresha Sampathi Perera ${ }^{2}$, Jaekyoon Kim ${ }^{3}$, Noreena Sweeney ${ }^{1}$, \\ Andrea Imhoff ${ }^{1}$, Adam J. Wargolet ${ }^{4}$, Rochelle M. Van Hart ${ }^{4}$, Andrew Craig Mackinnon ${ }^{5}$, \\ Karyn M. Frick ${ }^{3}$, Daniel S. Sem ${ }^{1}$ and William A. Donaldson ${ }^{2, *}$ \\ 1 Department of Pharmaceutical Sciences, Concordia University Wisconsin, Mequon, WI 53097, USA \\ 2 Department of Chemistry, Marquette University, Milwaukee, WI 53201-1881, USA \\ 3 Department of Psychology, University of Wisconsin-Milwaukee, Milwaukee, WI 53211, USA \\ 4 Department of Natural Sciences, Concordia University Wisconsin, Mequon, WI 53097, USA \\ 5 Department of Pathology, Medical College of Wisconsin, Milwaukee, WI 53226, USA \\ * Correspondence: william.donaldson@marquette.edu \\ + Presented at the 2nd Molecules Medicinal Chemistry Symposium (MMCS): Facing Novel Challenges in \\ Drug Discovery, Barcelona, Spain, 15-17 May 2019.
}

Published: 15 August 2019

\begin{abstract}
Estrogen receptor-beta (ER-beta) is a drug target for memory consolidation in postmenopausal women, while estrogen receptor-alpha (ER-alpha) is linked with the proliferation of certain breast cancer cell lines. While the ligand-binding domains of ER-beta and ER-alpha share less than $60 \%$ sequence homology, the ligand-binding pockets of the two subtypes have only minor differences in structure and composition. Nonetheless, these minor differences make the ER-beta binding pocket smaller in volume ( $\left.282 \AA^{3}\right)$ compared to the ER-alpha binding pocket $\left(379 \AA^{3}\right)$. We report a series of potent and selective ER-beta agonists with in vivo efficacy that are A-C estrogens, lacking the $\mathrm{B}$ and $\mathrm{D}$ rings of the endogenous ligand, estradiol (E2). The most potent and selective A-C analog activates the ER-beta isoform over the ER-alpha isoform by 750-fold, with an EC 50 of 27 $\pm 4 \mathrm{nM}$ in cell-based functional assays. The compound exhibits in vivo efficacy for memory consolidation for object placement and object recognition in an ovariectomized mouse model at a $0.5 \mathrm{mg} / \mathrm{kg}$ dose by intraperitoneal injection and by oral gavage. This analog does not activate seven other nuclear hormone receptors, does not inhibit CYP1A2 or CYP2D6 and has only weak inhibition of CYP2C9 and CYP3A4, and does not cause significant proliferation of MDF-7 breast cancer cells at doses up to $1000 \mathrm{nM}$.
\end{abstract}

Keywords: estrogen receptor agonist; SERBAs; memory consolidation; menopause; drug development

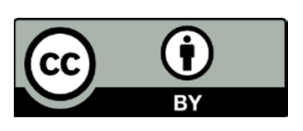

(C) 2019 by the authors. Licensee MDPI, Basel, Switzerland. This article is an open access article distributed under the terms and conditions of the Creative Commons Attribution (CC BY) license (http://creativecommons.org/licenses/by/4.0/). 